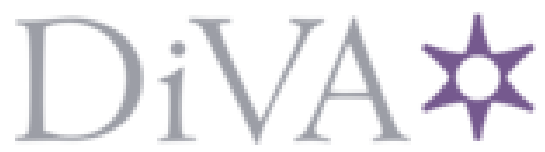

http://www.diva-portal.org

This is the published version of a paper published in International Criminal Justice Review.

Citation for the original published paper (version of record):

Iqbal, A., Ceccato, V A. (2015)

Is CPTED Useful to Guide the Inventory of Safety in Parks?: A Study Case in Stockholm, Sweden.

International Criminal Justice Review, 26(2): 150-168

https://doi.org/10.1177/1057567716639353

Access to the published version may require subscription.

N.B. When citing this work, cite the original published paper.

Permanent link to this version:

http://urn.kb.se/resolve?urn=urn:nbn:se:kth:diva-194663 


\title{
Is CPTED Useful to Guide the Inventory of Safety in Parks? A Study Case in Stockholm, Sweden
}

International Criminal Justice Review I-19

(C) 2016 Georgia State University Reprints and permission: sagepub.com/journalsPermissions.nav DOI: $10.1177 / 10575677 / 6639353$ icj.sagepub.com

(ASAGE

\section{Asifa Iqbal' and Vania Ceccato'}

\begin{abstract}
Crime prevention through environmental design (CPTED) has long been suggested as a guideline for improving safety in neighborhoods. Yet, little is known about the application of CPTED to urban parks. The aim of this study is to evaluate the adequacy of CPTED principles in guiding the inventory of safety conditions of an urban park. The study begins with a review of the development of CPTED ideas and then focuses on the inspection of a park with a relatively high level of crime in the city of Stockholm, the capital of Sweden. Site observations, parks inspection, crime mapping of policerecorded data, and interviews with selected users and municipal stakeholders underpin the methodology used in this study. Findings indicate that design and management of the park affect the park's safety conditions-attributes that are easily identifiable when using CPTED as guidance. The article concludes with several general lessons from using CPTED principles to inventory safety in parks.
\end{abstract}

\section{Keywords}

crime, perceived safety, green areas, physical environment, Sweden

\section{Introduction}

Crime prevention through environmental design (CPTED) is a place-based set of strategies for reducing crime and improving perceived safety (Cozens, Hillier, \& Prescott, 2001; Cozens, Saville, \& Hillier, 2005; DeKeseredy, Donnermeyer, \& Schwartz, 2009; Saville \& Cleveland, 1998). Despite having been around since the early 1970s (Jeffery, 1971; Newman, 1972), CPTED has been primarily applied to housing developments and neighborhoods in both urban and rural areas (Armitage, 2000; Atlas, 2008; Clarke, 1989; Cozens et al., 2001; DeKeseredy et al., 2009), commercial properties and shopping malls (Clarke, 1989; Schneider \& Kitchen, 2002), and transportation systems (Ceccato,

\footnotetext{
' Department of Urban Planning and Environment, School of Architecture and the Built Environment, KTH Royal Institute of Technology, Stockholm, Sweden

Corresponding Author:

Asifa lqbal, Department of Urban Planning and Environment, School of Architecture and the Built Environment, KTH Royal Institute of Technology, Stockholm SE-100 44, Sweden.

Email: asifai@kth.se
} 
2013; Ceccato \& Uittenbogaard, 2014; La Vigne, 1996; Loukaitou-Sideris, 1998; Mayhew, 2001; Newton \& Ceccato, 2015; Solans, 2013). Much less evidence is found in the literature about the use of CPTED to inventory safety in urban parks (see Beeler, 2011; McCormick \& Holland, 2013).

The aim of this study is to contribute to this research by evaluating the use of CPTED principles to inventory safety in urban parks. This aim is achieved by (1) adapting CPTED principles as an inventory tool to inspect safety in urban parks, (2) illustrating the matches and mismatches between CPTED principles and safety conditions in a high-crime park in Stockholm, Sweden, and (3) assessing the usefulness of CPTED principles in guiding safety conditions in urban parks.

A park was chosen as a unit of analysis for several reasons. CPTED principles have often been applied to public, semiprivate, and private areas in a relatively large scale, such as neighborhoods. The challenge is to look primarily at the unit of a park which is intrinsically a public space that is meant to be open to all. Another reason to use a park as a case study is the fact that parks represent a common site for recreational activities and esthetical experiences for everyone (Chiesura, 2004; Iqbal, 2012; Iqbal \& Ceccato, 2015). They are said to improve individuals' physical and mental health (Edwards \& Tsouros, 2006), but they may also be a criminogenic place, and for this reason, residents and other temporary users may avoid them (Ceccato \& Hanson, 2013). This also means that safety in parks goes beyond the tangible space and is dependent on those who experience it.

\section{Theory of CPTED}

The seminal ideas of CPTED can be traced back more than 50 years ago by Jacobs (1961). Jacobs criticized modernistic urban planning for creating insecurity and the negative atmosphere that prevailed in the streets of North American cities. She argued in favor of the "traditional city" with its mixed land-use functions. Jacobs suggested the notion of "eyes on the street" to support the use of high-density, mixed use communities (areas with both residential and commercial uses) so as to promote the surveillance of public spaces and streets (Ceccato, 2014). Jacobs" "eyes on the street" was certainly a new way to promote the discussion of old inner-city problems such as lack of "social control" in areas characterized by social disorganization, Shaw and McKay (1942) to a new audience, especially to urban planners and architects. The role of environment in promoting safety became clearer through the work of Jeffery (1971). Most of the elements in his approach are similar to the ones proclaimed a year later by Newman (1972). The need to associate environmental features with crime occurrence was developed through the principles of surveillance, territoriality, access control, target hardening, activity support, and image/maintenance (Newman, 1972). CPTED has developed in urban planning and criminology in separate but interconnected, overlapping paths. The environmental approach evolved through the work done by those interested in the role of place in crime occurrence and situational conditions of crime (e.g., Brantingham \& Brantingham, 1984; Cohen \& Felson, 1979; Madensen \& Eck, 2008; Reynald, 2009; Weisburd, Telep, \& Baraga, 2010), crime causation (e.g., Wikström, Ceccato, Treiber, \& Hardie, 2010), and situational crime prevention (e.g., Clarke, 1997, 1989; Ekblom, 2010; Tilley, 2005).

Since the 1970s, there have been major efforts to move away from deterministic ideas linking crime to particular physical environmental characteristics. CPTED has therefore progressed to include social and technological dimensions of crime prevention and safety schemes. This development can be illustrated the different generations of CPTED (Saville \& Cleveland, 1998, 2008; United Nations Interregional Crime and Justice Research Institute [UNICRI], 2012). While in CPTED first generation the location and the design of a building were considered to be highly relevant to discourage crime events (Cozens et al., 2005; Saville \& Cleveland, 1998; UNICRI, 2012), the second-generation principles attempted to combine place's physical features with the social dimension of the environment and promote safety as part of sustainable development through social cohesion, connectivity, and community participation (Saville \& Cleveland, 2008). A more 
recent development occurred with the introduction of what may be called "third-generation CPTED." The principles of the third generation rely on the potential of technology solutions to improve safety while adopting a green approach: "Future cities need a symbiotic and synergistic relationship with the global natural ecology" (UNICRI, 2012, p. 54). Yet, it continues to emphasize the need of inclusive communities and the redesign of the physical environment to reduce crimes by upholding the principles of surveillance and access control from the first generation as well as physical design effectiveness and sociocultural diversity from the second generation (UNICRI, 2012, p. 23). CPTED has also become sensitive to the different needs of those who consume and experience urban space, reflecting the safety concerns of women, elderly individuals, and individuals with disabilities (Ceccato \& Hanson, 2013; Cubbage \& Smith, 2009).

In the Nordic countries, it has taken decades for some of these principles to be implemented. A reason for this delay is that the Nordic model for crime prevention is a combination of social welfare policies and situational prevention strategies (Johansson, 2014; Takala, 2004), in which CPTED played a marginal role. Grönlund (2012) stated that the implementation of CPTED guidelines started in the late 1990s in Sweden. These guiding principles involved the planning of housing, transport, municipal facilities, and parks (Grönlund, 2012). A social turn in local crime prevention practices in the 1990s in Sweden pushed community policing to the forefront, resulting in less attention being given to the physical environment (and, therefore, CPTED). It was not until 2005 that the National Housing Board launched a number of initiatives incorporating the CPTED principles. One of the most famous was Botryggt05, which was documented by Stockholm police in 2005 . This initiative centered on the inclusion of CPTED measures in housing construction guidelines. The crime prevention program in Sweden is focused on three different approaches: (a) reducing opportunities to commit crime, (b) reducing recruitment to criminal lifestyles, and (c) reducing criminal activity among persistent offenders (Brottsförebyggande rådet [Brå], 2014). Gendered safety has also become part of the national housing agenda to a greater extent than in the past (Boverket, 2010). Various attempts have been made to create new sustainable housing in Sweden, with the initial CPTED principles being an important part of the planning and construction (Grönlund, 2012). Today, these principles are still considered guidelines and are far from being regarded as the standard of practice in housing and planning.

\section{CPTED Principles}

The most known CPTED principle relies around the notion of surveillance that can encompass in many ways. Formal surveillance is often carried out by local stakeholders, including security guards and shopkeepers (users of the space), whereas informal surveillance is performed by residents and/or transients of a place (Hilborn, 2009). Open line of sight in park by guardians and handlers and park managers (such as workers at coffee places and mothers with pram) can help to enhance natural surveillance (Felson, 1995). The implementation of closed-circuit television (CCTV) cameras has been considered a supplemental tool for surveillance and a potential means of facilitating social control (Moffat, 1983; Reynald, 2014). Natural surveillance can also be facilitated by creating the sense of territoriality. Territoriality refers to how the physical design can develop a sense of ownership in specific areas (Reynald, 2014). Cozens, Saville, and Hillier (2005) pointed out that territoriality can be achieved by ensuring all spaces a specific and designated purpose. In the second generation of CPTED, Saville and Cleveland (2008) stated that sense of ownership can help to create the idea of shared standards among different user groups (including gender perspective and people with special needs), while, in the third generation of CPTED, territoriality can be promoted by sharing real-time information about what is happening in the place and in the immediate surroundings (UNICRI, 2012).

Designing spaces with a specific purpose can also help to regulate access. Access control refers to property control by barriers, enclosures, and entry portals. Reynald (2014) showed that smaller identifiable zones can make access control easier and that the controlled flow of movement through 


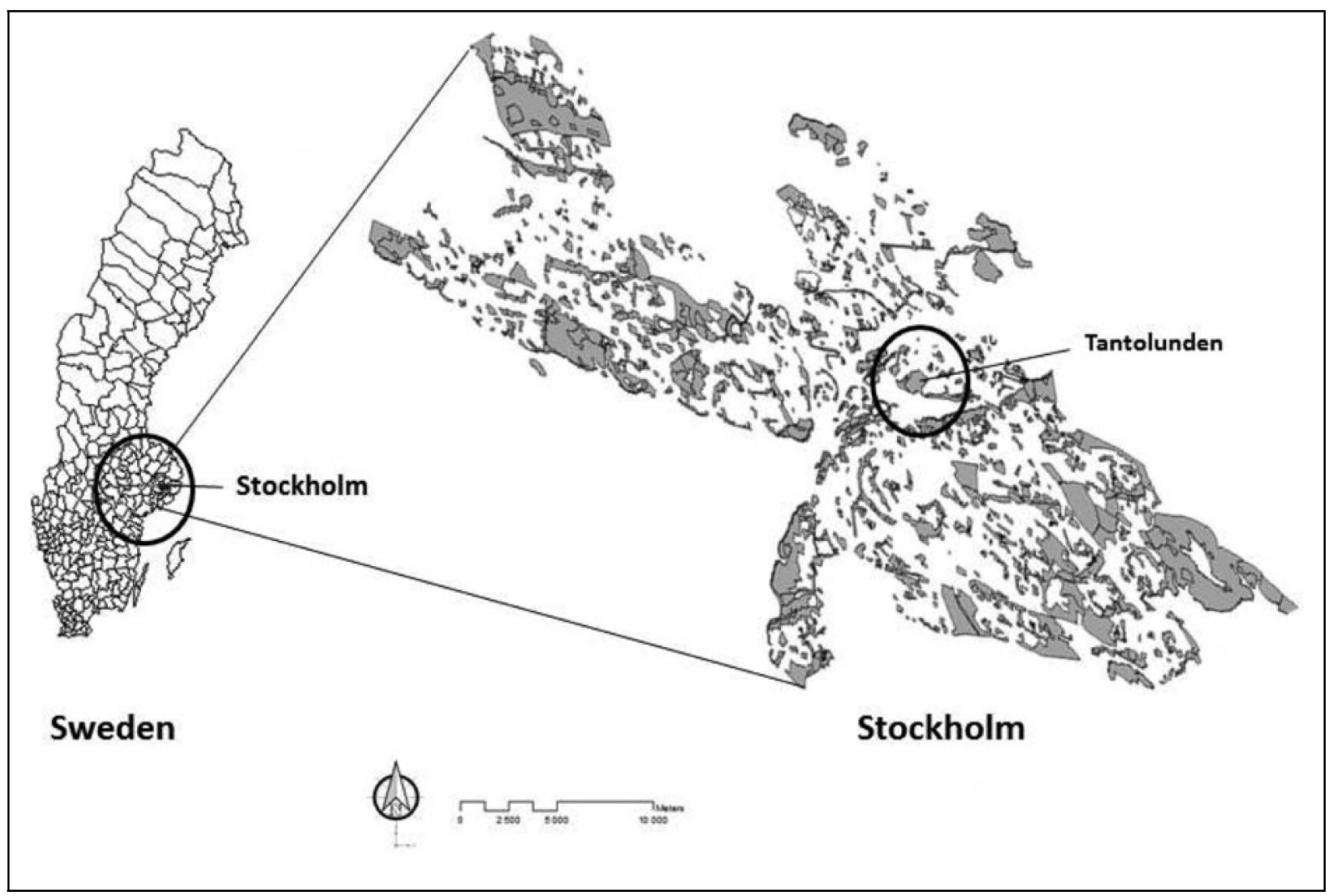

Figure I. Tantolunden Park in Stockholm, Sweden.

regulated access can help reduce crime. Access control in the third generation of CPTED can be related to pedestrian-friendly urban streetscapes (UNICRI, 2012) in smart cities by installation of safety information signs through wireless network transmissions (audio/video). Selective restriction of access can also be done by target hardening. Target hardening is about how the design of a space can make it difficult for people to steal or damage private and/or public property (e.g., by installing padlocks). Cozens et al. (2005) warned that overuse of target hardening measures can lead to the development of a "fortress mentality" (p. 338). To avoid fortress mentality, activity support encourages interactions between residents and other users, thereby discouraging crime (Saville \& Cleveland, 2008). Image of the place/maintenance informs how the esthetical pleasantness of the environment can enhance the perceived safety of the area and keep potential criminals away because well-kept environments show that people are in control of the area. Conversely, lack of maintenance can encourage crime to occur because formal social control/surveillance is not present, which leads to the progressive abandonment of the space by local citizens (Wilson \& Kelling, 1982).

\section{The Study Area}

The area of Stockholm municipality is $214.7 \mathrm{~km}^{2}$, with parks and green spaces covering an area of $64.947 \mathrm{~km}^{2}$ (City of Stockholm, 2009), which is more than one third of the municipality area. Stockholm has 1,046 parks and green spaces classified under three major categories (for more details, see City of Stockholm, 2006). Tantolunden is classified as a hilly inner-city park in Södermalm, which is one of the most densely populated districts in southern Stockholm municipality (Figure 1). The area also has two of Stockholm's main transportation hubs (Skanstull and Medborgarplatsen).

Tantolunden was chosen as a study area because it is a well-known park and has long been part of the "local identity" of Södermalm (Rönngren, 2014). Yet, it is also a criminogenic park with many 


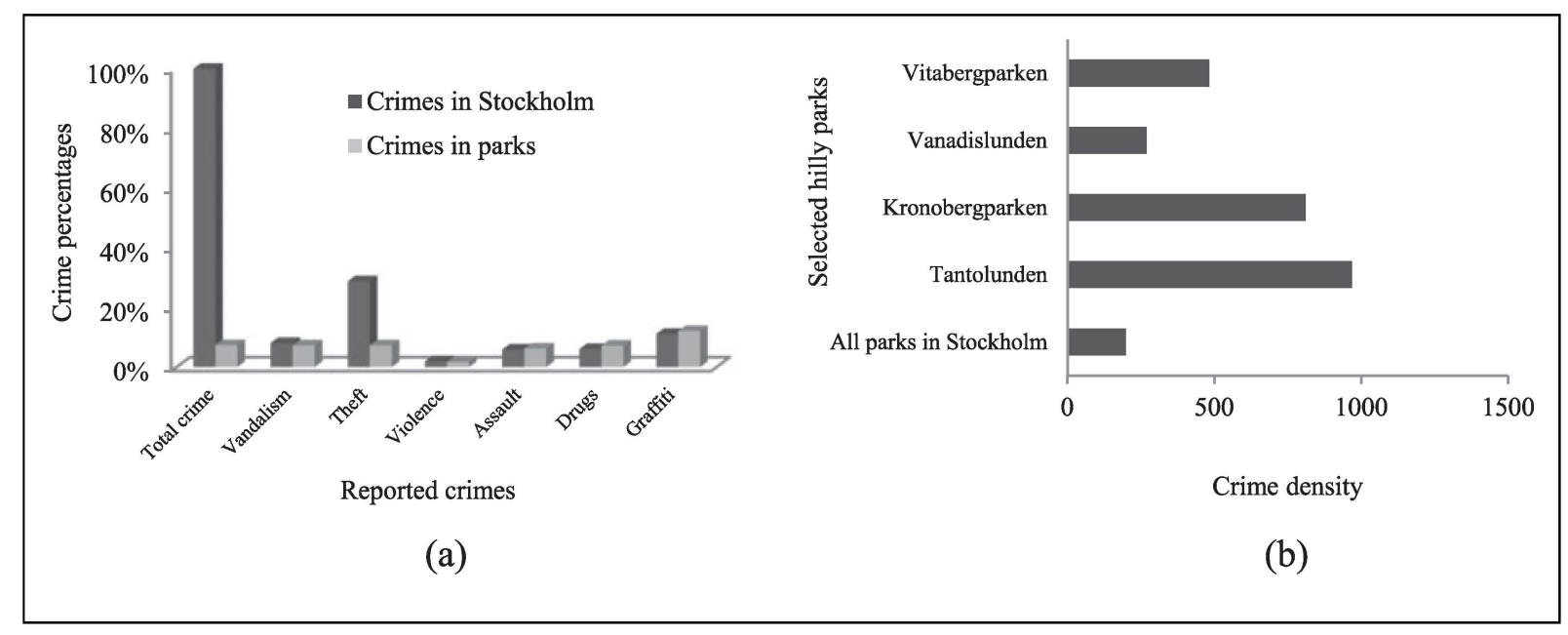

Figure 2. (a) Crimes in Stockholm municipality and in parks (2008). (b) Density of crimes in selected hilly parks $\left(\mathrm{crime} / \mathrm{km}^{2}\right)$. Note. Adapted from Police statistics, 2008.

safety challenges, with one of the highest violent crime rates in Stockholm municipality (Iqbal, 2012). Tantolunden was designed as a system of pathways leading toward its highest topographical point (a hill) and is close to two important transportation hubs. As an inner-city park, Tantolunden is home to various facilities and activities throughout the year, including Stockholm's largest youth festival, ball games, mini golf, volleyball, playgrounds, picnics, and contact with nature. Tantolunden is also famous for its community garden plots and cultural heritage elements from the $1700 \mathrm{~s}$ (Södermalm District Administration, 2009).

Figure 2 a shows that $7 \%$ of total crimes (mostly graffiti and vandalism) in 2008 happen in parks and open green spaces in Stockholm and that $13 \%$ of all park crimes happen in Tantolunden (Police statistics, 2008). Theft is the most frequently reported crime in Stockholm (29\% of all crimes), followed by graffiti (11\%) and vandalism (8\%). Narcotics and assault are tied for the fourth most common type of reported crimes ( $6 \%$ of the total number of reported criminal acts) and various types of violent crimes (2\%). Figure $2 \mathrm{~b}$ shows the crime rates for all parks in Stockholm and for Tantolunden Park and three other hilly inner-city parks.

\section{Method}

A mixed method approach (see, e.g., Creswell, Klassen, Clark, \& Smith, 2010) was used to assess the effectiveness of CPTED for parks. This mixed method approach entailed collecting, analyzing, and blending both qualitative and quantitative data without linking these two types of data. The central idea behind using both qualitative and quantitative perspectives (rather than adopting a single perspective) is that they allow a better understanding of the problems being researched (Clark \& Creswell, 2011). Crime mapping, field inspection, people counting, and interviews were used as basis for the inventory in this study (Table 1).

First, the park was split into various geographical zones (eclipses) to allow the identification of specific land uses of the park and their problematic areas (stars showing crime locations, Figure 3 ). Zone A comprises the area on the Drakensberg side, which includes mini golf, public toilets, and water frontage; Zone B includes a day care center, a small ball field area, and the area in front of the apartments located at Drakenbergsgatan. Zone C comprises the main football field and its surroundings, which include community garden plots and a part of the hill. Zone D encompasses the highest point of the hill in Tantolunden, an off-leash dog play area, and a few community garden plots. Zone $\mathrm{E}$ is mainly dotted with community garden plots. 
Table I. Methods Used When Inventorying Safety in a Park Using CPTED Principles.

\begin{tabular}{lcccc}
\hline CPTED Principles & Crime Mapping & Field Inspection & People Counting & Interviews/E-mail \\
\hline Surveillance & & $\checkmark$ & $\checkmark$ & $\checkmark$ \\
Territoriality & $\checkmark$ & $\checkmark$ & & \\
Access control & $\checkmark$ & $\checkmark$ & $\checkmark$ & \\
Target hardening & & $\checkmark$ & & $\checkmark$ \\
Activity support & & $\checkmark$ & & $\checkmark$ \\
Image of the place & & & \\
\hline
\end{tabular}

Note. CPTED = crime prevention through environmental design.

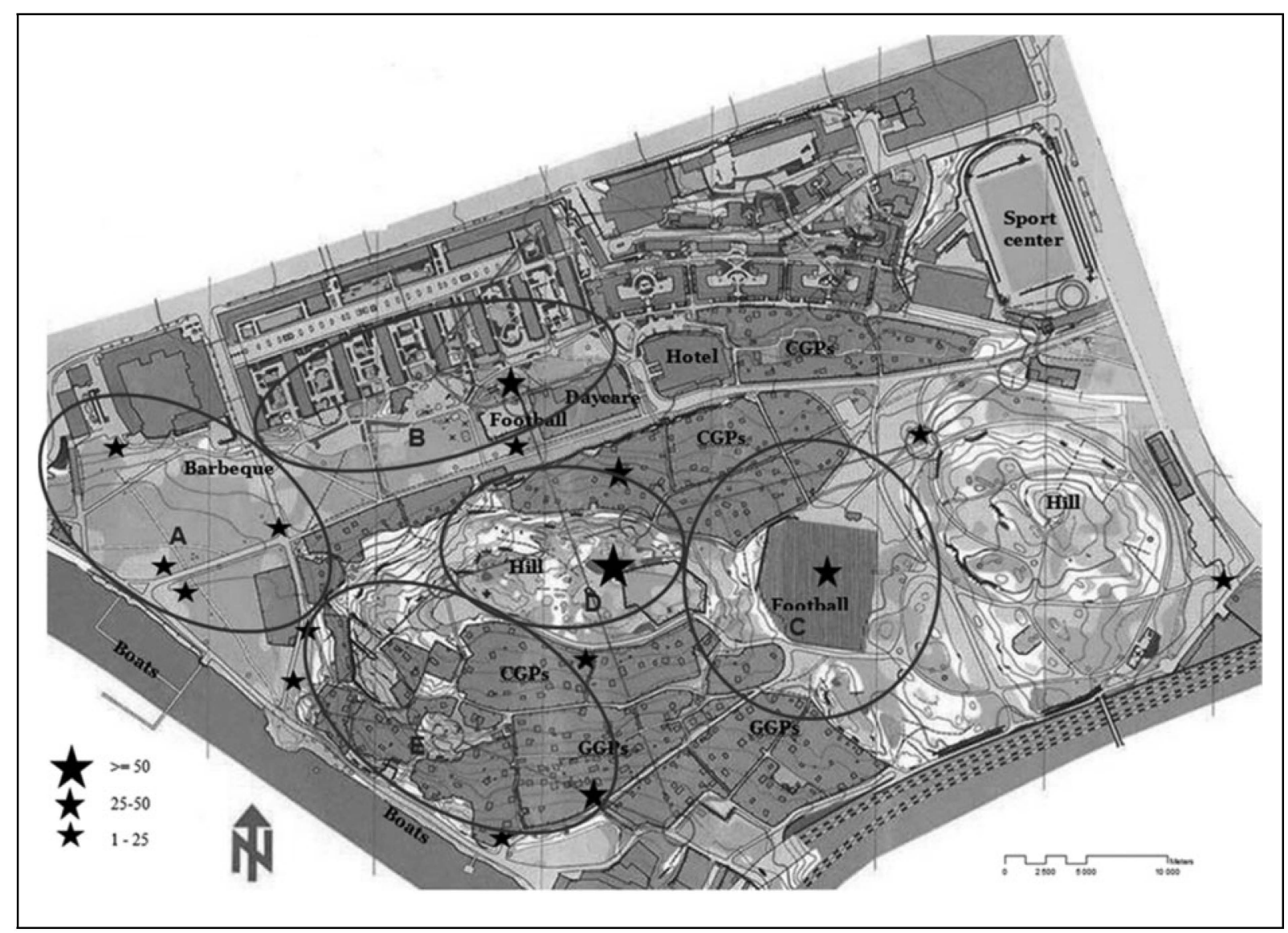

Figure 3. Crime locations (stars) and zones of inspections.

Second, crime events in the park were mapped (1-year data set, from Stockholm Police Headquarters) and mapped by using geographical information systems. Crime concentrations were later visited during field inspection. Third, a field inspection was performed using CPTED principles using a checklist created based on CPTED principles (Appendix). Across the six CPTED principles, a total set of 54 features were compiled into a checklist. The checklist was developed by extracting relevant items from existing CPTED checklists available on the Internet. This "final" checklist was then used to record the presence or absence of these features in the park (see e.g., City of Hamilton, 2006; Rowan, 2006; Teskey, 2013).

The inventory was conducted in the autumn (October-November 2014), and given this time of year, the activities in the park were influenced by weather conditions, which were somehow limited with those expected in the summer. Park users were analyzed based on their activities, such as 
Table 2. Park Users and Crime at Tantolunden Park.

\begin{tabular}{llcccr}
\hline Selected Points/Time & Day and Date & $\begin{array}{c}\text { Number } \\
\text { of Bikes }\end{array}$ & $\begin{array}{c}\text { Number of } \\
\text { Pedestrians }\end{array}$ & Total & $\begin{array}{r}\text { Total } \\
\text { Crimes }\end{array}$ \\
\hline Zone A, 09:00-12:00 & Monday, October 27, 2014 & 9 & 67 & 76 & 9 \\
Zone B, 13:00-15:00 & Sunday, November 16, 2014 & 4 & 27 & 31 & 35 \\
Zone C, 15:00-17:00 & Wednesday, November 5, 2014 & 2 & 55 & 57 & 48 \\
Zone D, 13:00-15:00 & Thursday, November 6, 2014 & 5 & 16 & 21 & 219 \\
Zone E, 09:00-12:00 & Friday, October 31, 2014 & 7 & 58 & 65 & 31 \\
\hline
\end{tabular}

Note. Adapted from Fieldwork, 2014 (October-November).

walking, passing through the area, waiting, playing, jogging, and working. The observations across the park were carried out 5 times during different hours of the day-roughly from 0900 to 1200 hours, 1300 to 1500 hours, and 1500 to 1700 hours on weekdays and from 1300 to 1500 hours on one weekend. Counts of park users (pedestrians and bike users) at selected areas were also performed at certain times of the day and on certain days of the week (Table 2).

Fourth, semistructured interviews with park users were performed during the fieldwork. This approach was chosen because it allows for more spontaneous conversations, thereby providing greater opportunity to ask follow-up questions. Given the time of the year, not many park users were around, and four interviews were conducted with park users (two males and two females aged 18-40 years). They were asked about daily routine in the park, engagement in park activities, and reasons for considering Tantolunden as a safe or an unsafe park. Moreover, in order to understand activity support in Tantolunden Park, a questionnaire was sent by e-mail to the park manager and a crime prevention coordinator in Stockholm municipality. The questionnaire contained questions about CPTED principles in the park's planning, design, activity support, and other crime prevention initiatives. Information from interviews and questionnaires has provided a limited yet complementary view of the data collected in the field inspection and of the police-recorded crime data.

\section{Results}

The results of this study are divided into three sections. The first section shows how CPTED principles can be adapted as a safety inventory tool to an urban park. The second section uses Tantolunden as an example and illustrates the matches and mismatches between CPTED principles and the safety conditions of the park. Finally, Section 3 assesses the usefulness of CPTED principles in guiding the inventory of safety conditions in urban parks using the experience with Tantolunden as a reference.

\section{Adapting CPTED Principles to Urban Parks}

CPTED principles have primarily been applied to housing developments and neighborhoods, commercial properties and shopping malls as well as transportation systems. Below we discuss whether and how CPTED principles can be turned into features that are identifiable in a park and function as an inventory tool to identify safety problems.

Well-maintained trees and foliage in parks, trimmed bushes, proper lighting, and adequate park furniture can produce clear sightlines and promote natural surveillance. The placement of park furniture can work as a source of monitoring while improving social ties among park users. Yet, they may also create places for noise and public intoxication (Saville \& Cleveland, 2008). Litter, graffiti, and other problems are common in large-size parks. Removal of interstitial spaces can serve to reduce crime opportunities in parks and can also be helpful to facilitate access for users with special 
needs. Proper maintenance and sense of ownership among residents (Newman, 1972) and park users create positive image of the park. Interface between authorities and citizens creates a sense of belonging, which can also help to improve the image of the park. Increased levels of social cohesion and informal social control produce positive esteem and place attachment, which thereby may result in a better maintained park.

Equally important is territoriality in a park that can be promoted through distinguishing public, semipublic, and private spaces from one another through physical features, such as signage, flower beds, pavement treatments, landscaping, and artwork. Territoriality and natural surveillance can be promoted by adequate illumination (e.g., light-emitting diode) and real-time information (e.g., through screens and signage for park users; UNICRI, 2012). Place identity and a sense of shared standards among different groups of park users (Saville \& Cleveland, 2008) can also enhance territoriality. Moreover, limitation of the number of pedestrian routes and installation of low hedging or low open-type fencing around the periphery of the park or a particular area can be used to prevent children from running out onto the street (Atlas, 2008). Interaction between users, park managers, and workers in parks can support access control through the presence of watch groups and personnel staff. Pedestrian-friendly streets as well as entrances can help to improve the access to parks for the users, especially those with specific needs. Physical boundaries through planting hedges and bushes, installation of gates and fences in parks, make a target difficult to steal or damage (Newman, 1972) while improving sense of community and social cohesion among park users and reducing the need for physical measures of target hardening (Saville \& Cleveland, 2008). Surrounding activities at the park and adjoining land uses influence the activity support. Collective activities (such as night security watches, holiday jobs for school students, and other community events) allow socializing among various specific users. Targeted online platforms in parks raise voices to communicate needs, concerns, and ideas for specific users (UNICRI, 2012).

\section{Inspecting CPTED Principles in Tantolunden Park}

Table 3 summarizes the overall inventory of CPTED principles based on the field inspection in Tantolunden. Features of territoriality, activity support, and target hardening were visible, while park maintenance was also found to be unsatisfactory. With regard to access control, the design of the park was found to be permeable, and its size makes it difficult to control the whole area. Surveillance was observed by the presence of people in the park during daytime hours in some places (e.g., places near the day care center in Zone B and near the metro station at Hornstull in Zone A), whereas potential for surveillance was almost nonexistent in other places (the backside of football area in Zone $\mathrm{C}$ and the high hill point in Zone D).

Potential for natural surveillance also differed throughout the day (Table 2). For example, the people count in Tantolunden showed that potential opportunities for surveillance in Tantolunden were mostly in the morning (0900-1200 hours in Zones A and E) and late afternoon hours (1500 to 1700 hours in Zone $\mathrm{C}$ when sports activities were being held in the football field). Yet, the conditions for natural surveillance in Tantolunden are limited in part because of the park's topography. Tantolunden is built on a natural hill, visibility is limited, and there are many escape routes and places to hide (e.g., the community garden plots during the dark winter months). Moreover, some of the pathways and transitional areas had poor sight lines owing to overgrown vegetation and barriers, thus making natural surveillance difficult and providing favorable conditions for vandalism and other types of crimes. In Tantolunden, some pathways in Zones $\mathrm{C}$ and $\mathrm{E}$ between the community garden plots were not well lit compromising surveillance (Table 4).

Another relevant issue is whether surveillance can be improved in most problematic points through the presence of guards and CCTV cameras. Neither CCTV cameras nor security guards were detected in the Tantolunden Park at the time of field inspection (Table 4). In the United States, 
Table 3. Overall Inventory of CPTED Principles in Tantolunden Park.

\begin{tabular}{lccc}
\hline CPTED Principles & Visible & Limited & Not Visible \\
\hline Surveillance & & $\checkmark$ & \\
Territoriality & $\checkmark$ & & $\checkmark$ \\
$\begin{array}{l}\text { Access control } \\
\text { Target hardening }\end{array}$ & $\checkmark$ & $\checkmark$ & \\
$\begin{array}{l}\text { Activity support } \\
\text { Image of the place }\end{array}$ & & & $\checkmark$ \\
\hline
\end{tabular}

Note. CPTED = crime prevention through environmental design.

$\checkmark$ refers to the presence of this specific CPTED principle once observed in the fieldwork in the park.

Table 4. Evaluation of CPTED Principles for Urban Parks.

\begin{tabular}{ll}
\hline CPTED Principles & Advantages \\
\hline Surveillance & *Pathways through parks encourage \\
observation in less visible zones. \\
*Guardians (e.g., daily users, transients, and \\
park workers) protect targets in parks \\
from being victimized; place managers \\
(e.g., park keepers) supervise specific \\
places in parks, and handlers (e.g., coffee \\
shop owners) supervise potential \\
offenders. \\
*Good illumination, especially in dark \\
months of the year, is fundamental for \\
surveillance. \\
CCTV cameras can be installed in high-crime \\
areas of parks (e.g., parking lots, bicycle \\
parking places)
\end{tabular}

Challenges

*Flow of people through the park creates also opportunities to crime

*Although coffee shops and kiosks allow "eyes on the park," they can also generate the right conditions for crime.

For economic and ecological reasons, the extensive illumination of parks may not be feasible because of the high energy consumption, for example, some parks in Sweden turn off the lights after 2300 hours.

*The busy summer season demands extra attention in parks. Moreover, sight lines can be interrupted in certain areas of parks owing to not only the topography (hills, ditches, tunnels) but also the variations in daily and seasonal natural light, especially in Scandinavian cities that experience short days during the winter months.

*The need for permission to install CCTV cameras in public places in Sweden limits their use in parks

Territoriality *Land use of the park determines where the

*By definition, parks are open spaces. Thus, potential boundaries should be.

*Distinct separations between semi-private (e.g., gardens) and public spaces make it easy to identify and deal with trespassers, especially when special events (e.g., festivals) are held

Access control *Park visitors should be encouraged to follow signs with regard to the designation of private, semiprivate, and public spaces. The number of dead-end streets in parks should be limited so as to minimize the number of places with low visibility. park users must be informed about restricted areas, through maps and signage, to avoid trespassing in protected zones

*A limited number of access routes create poor flexibility in movement, especially for users with special needs (elderly/ disabled park users).

* Large parks cannot be made hermetic. Open access areas may allow intruders to enter no-go zones of parks. 
Table 4. (continued)

\begin{tabular}{|c|c|c|}
\hline CPTED Principles & Advantages & Challenges \\
\hline & $\begin{array}{l}\text { *Designing natural barriers helps to create } \\
\text { boundaries (e.g., with pavement } \\
\text { textures) without the need for gates. } \\
\text { However, installing gates and other } \\
\text { security measures (CCTV) may be } \\
\text { necessary in large parks to keep control } \\
\text { of the flow of users and parking lots. } \\
\text { * Road traffic should be kept to a minimum, } \\
\text { and the number of high-speed roads } \\
\text { through parks should be limited. Parking } \\
\text { lots for park visitors should be located in } \\
\text { visible areas }\end{array}$ & $\begin{array}{l}\text { *Roads through parks should give priority to } \\
\text { public transportation instead of private } \\
\text { cars. } \\
\text { *This topic opens up a discussion about the } \\
\text { challenges of implementing segregated } \\
\text { and gated zones and other measures to } \\
\text { deter illegitimate users within public } \\
\text { places }\end{array}$ \\
\hline Target hardening & $\begin{array}{l}\text { *Target hardening makes it more difficult for } \\
\text { offenders to commit crimes and makes it } \\
\text { easier for park managers to enhance the } \\
\text { boundaries of spaces. It involves the use } \\
\text { of security measures that go beyond } \\
\text { design features (e.g., padlocks and iron } \\
\text { bars) }\end{array}$ & $\begin{array}{l}\text { *Target hardening can compromise the } \\
\text { esthetics of parks. } \\
\text { *Crime hot spots must first be identified. } \\
\text { *The implementation of target hardening } \\
\text { measures demands the earmarking of } \\
\text { resources }\end{array}$ \\
\hline Activity support & $\begin{array}{l}\text { *Activity support promotes multiple uses of } \\
\text { parks and collective community services } \\
\text { (e.g., gardening and mobile libraries } \\
\text { located in parks). } \\
\text { * "Safety walks" can be locally organized to } \\
\text { satisfy the needs of specific groups, such } \\
\text { as parents and children. } \\
\text { * Activity support calls for new ways of } \\
\text { approaching "safety" and "access to public } \\
\text { places" as human rights. The question } \\
\text { is-safety for whom? }\end{array}$ & $\begin{array}{l}\text { *Activity support assumes a degree of } \\
\text { knowledge and local attachment to a park } \\
\text { and its surrounding neighborhood. Parks } \\
\text { located in neighborhoods with high } \\
\text { population mobility may not be able to } \\
\text { promote activity support. } \\
\text { *It is difficult to engage all types of park users } \\
\text { with different interests. } \\
\text { * Conflicts may occur between frequent } \\
\text { park users, namely, local residents and } \\
\text { the so-called "illegitimate" park users } \\
\text { (homeless individuals, alcoholics/drug } \\
\text { users) }\end{array}$ \\
\hline Image of the place & $\begin{array}{l}\text { *The esthetics of parks is important as it } \\
\text { attracts visitors and reinforces local } \\
\text { identity. Regular maintenance of parks is } \\
\text { also a key. } \\
\text { *Good maintenance of parks (e.g., tree and } \\
\text { bush trimming) creates unobstructed } \\
\text { views for park users. The surveillance of } \\
\text { parks can be improved by constructing } \\
\text { low-rise structures instead of high-rise } \\
\text { structures and by preserving open spaces } \\
\text { as much as possible without } \\
\text { compromising the esthetic aspects of } \\
\text { parks. } \\
\text { *The number of garbage cans should be } \\
\text { maximized, and free walls should be } \\
\text { available for graffiti artists }\end{array}$ & $\begin{array}{l}\text { *Poor maintenance of parks can lead to the } \\
\text { overgrowth of dense or low-branching } \\
\text { vegetation, thereby limiting visibility and } \\
\text { surveillance as it can create entrapment } \\
\text { areas and reduce sight lines. } \\
\text { *Controlling litter and vandalism is difficult, } \\
\text { especially in large parks. } \\
\text { * More visitors mean more social } \\
\text { interactions, which in turn may lead to } \\
\text { more crime and require more } \\
\text { maintenance }\end{array}$ \\
\hline
\end{tabular}

Note. $\mathrm{CPTED}=$ crime prevention through environmental design; CCTV = closed-circuit television. 
McCormick and Holland (2013) found, for instance, that CCTV cameras can affect criminogenic conditions at the crime hot spots in urban parks. Yet, in Sweden, the need for permission to install CCTV cameras in public places limits their general use in parks and other public spaces.

In terms of territoriality, a clear separation between public and private spaces was found in some zones of Tantolunden, which contributes to the overall safety of the park, for example, between apartment blocks and the park and between the football area and the day care center in Zone B. Yet, these separations can create isolated spots. Most of the secluded areas with dark corners and hiding places were found in between community garden plots in Zone E, thereby making this zone a preferred location for thieves and burglars to lie in wait.

The size and location of Tantolunden Park also pose challenges to management and ensure safety. Tantolunden attracts many users from all over the city, and as a centrally located park, Tantolunden serves as a transitional permeable space by various group of users (e.g., pedestrians, cyclists, schoolchildren, parents with prams, elderly individuals, joggers, and dog walkers) creating many opportunities for crimes. The consumption of alcohol in the park (and the noise that often accompanies it) is observed in some zones of the park daily. Local residents and visitors to the park have indicated that the presence of alcohol and/or drug addicts in Tantolunden is a source of fear.

Previous research has revealed that increased accessibility can be associated with increased crime rates. The fieldwork evaluation of access control in Tantolunden Park was a challenge because of the topography of the park (hill) and numerous entrances and exit pathways (total 18 numbers of entrance and exit points with the exception of internal pathways and trails, some of which are not open to the public). The area that includes the community garden plots in Zones $\mathrm{C}$ and $\mathrm{E}$ is punctuated by "leaking" walkways, providing safe escape routes as well as entrapment points for offenders to exploit victims. Designing natural barriers may help to create boundaries without the need for gates. However, installing gates and CCTV may be necessary at particular spots to keep control of the flow of different users and parking lots (Table 4). Places with more than one pathway/ exit usually had many cases of violent crimes, but note that more than half of the violent crimes carried out in Tantolunden Park occurred in the sports area and the community garden plots in Zones $\mathrm{C}$ and $\mathrm{D}$ (Table 2).

In terms of target hardening, extra safety measures were noticed within the community garden plots in Zone $\mathrm{E}$ and the pathways in Zone $\mathrm{A}$. The implementation of these measures was regarded as a clear indication of fear of burglary (Figure 4a, e, and f). Extra safety gates and fences were also noticed at the football area so as to limit the people traffic in Zone $\mathrm{C}$, thereby helping to maintain a separation between public and private spaces (among all crimes, theft-related crimes are the highest in this area). Although gates and fences are a measure against burglars, MacDonald and Gifford (1989) suggested that they may actually increase the probability of being targeted by burglars because their presence help indicate which targets are more profitable. The use of padlocks and other safety measures also signalized that property crimes happen in the area. As these locks are visible to park users, they can also affect perceived safety in the park.

When it comes to activity support, Tantolunden Park offers some activities all year around, by the types of sports infrastructure available in the park, such as football field and jogging tracks. The park also offers some support for collective activities during certain times of the year, for example, grill parties and gardening in community garden plots. However, these areas impose challenges. At the time of field inspection, most all of the grill areas in Tantolunden Park were used by the homeless and those who visit the park to drink alcohol.

Activity support at the city level was found to be monitored by Söderandan, a local crime prevention council that serves Södermalm district and Tantolunden Park. The goal of Söderandan is to create a "cleaner, greener, and safer city" with the help of local authorities, including police and representatives from various fields in conjunction with schools, parents, and staff at youth recreation centers so as to control alcohol, smoking, and narcotics. A local website with a YouTube 


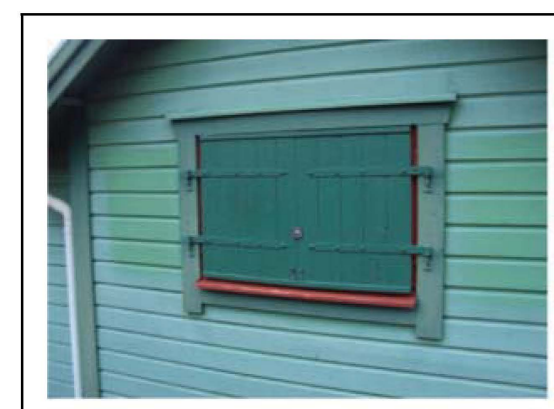

(a)

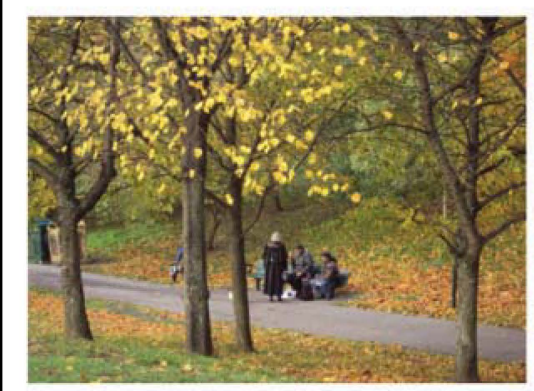

(d)

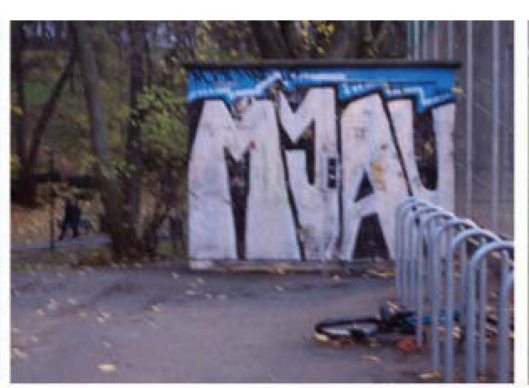

(b)

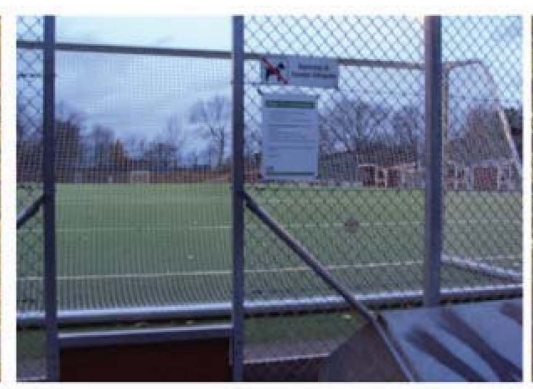

(e)

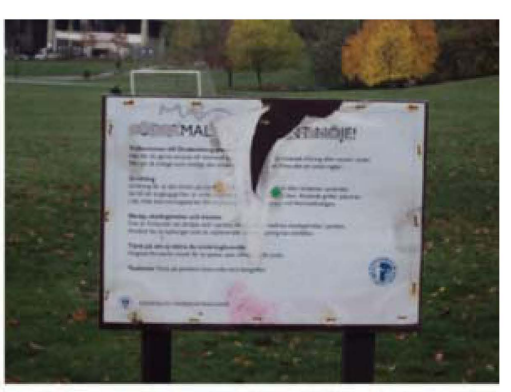

(c)

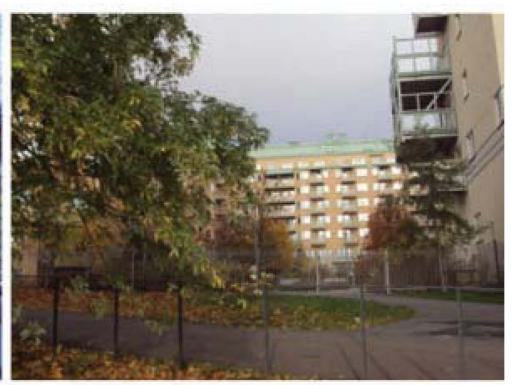

(f)

Figure 4. (a) Example of target hardening on the windows. (b) Graffiti near football area. (c) Signboards are vandalized. (d) Drinking in the park. (e) Limited access to football area. (f) Gates and fences to separate the park from the residential area.

channel (Söderandan, n.d.) help with the local communication among local residents (City of Stockholm, 2015). Yet, the maintenance of Tantolunden is the responsibility of the municipality and is far from being homogeneous; here we give some examples.

The community garden plot area next to the playground in Zone $\mathrm{C}$ is a perfect example of the "broken windows metaphor" (Wilson \& Kelling, 1982), with overgrown trees and shrubberies and litter near the football area, showing clear signs that nobody is in charge of the area. Graffiti can also be seen at many places in Zone C (Figure 4b). As suggested by Ley and Cybriwsky (1974), grafitti can be an indicator of attitudes, behavioral dispositions, and social processes in settings and that graffiti written by teenage gangs delineate their turf or area of control and can also serve as territorial markers. Free walls for graffiti artists may help to solve this issue (Table 4). However, graffiti is not the only problem. Most of the park benches along the side walkways in Zones A and $\mathrm{E}$ are vandalized (Figure 4d). In addition, the maintenance of public toilets in Zone A was identified as problematic as park users and residents pointed out that they avoid using public toilets in the park because they are frequently being used for other purposes, including drug use. Beeler (2011, p. 98) suggested that "non-CPTED complaint designed bathrooms" can be misused and thus can increase crimes.

\section{Assessing Usefulness of CPTED Principles to Urban Parks}

The strengths and challenges of applying CPTED principles to an urban park are summarized in Table 4. As this exercise indicates, parks are often thought as whole units, but they are often constituted by identifiable heterogeneous parts. For example, open spaces in the park (e.g., commons, open fields) impose limitations to the application of the concept of territoriality as a safety tool, while it is easier to implement this concept for semipublic areas (e.g., gardens, picnic areas), as they may already impose restrictions to access (e.g., clear separations between "gardens" and 
"picnic areas" make it easy to identify and deal with trespassers, while in an open field this task is not). Moreover, as a public space, it is not always clear how to identify "who is responsible for what" when managing a park since activities go over the boundaries of each functional area (for instance, sports fields). In practice, this means that an assessment of safety in parks using CPTED principles must take park's land-use heterogeneity and stakeholders' different responsibilities into account before setting out the inventory.

Another challenge with CPTED principles is that they overlap each other when applied in reality. Some examples are discussed here. Target hardening measures make it easier for the park managers to control, but they can compromise the esthetics of parks. Activity support promotes multiple uses of parks, but it is difficult to engage all types of park users with different, sometimes opposite interests. Good illumination, especially in dark months of the year, is fundamental for surveillance. Yet, for economic and ecological reasons, the extensive illumination of parks may not be feasible because of the high consumption of energy required to illuminate all parts of the park. Some of these dilemmas are illustrated in detail Table 4.

\section{Conclusions}

This study contributes to the research by evaluating the use of CPTED principles to inventory safety in Tantolunden Park, an urban park in Stockholm, Sweden. Crime mapping, field inspection of the park, people counting, and interviews were used as the basis for the inventory. Findings show that a relatively large urban park with a variety of land uses and many entrances, such as Tantolunden, challenges the principles of access control and territoriality and imposes limitations on park maintenance. Issues of limited surveillance caused by interrupted sight lines are also a problem in some of the zones in Tantolunden Park. Although a park should be accessed by all, some areas are not. The lack of signs indicating the specific use of areas (territoriality) may contribute to the confusion about "who can use what and when" in the park.

The analysis of CPTED principles in Tantolunden Park consistently revealed that crime concentrations are directly related to the design and maintenance of the park. The largest concentrations of narcotics-related crimes were observed around the community garden plots and the football area because these areas have numerous hiding places, particularly in certain seasons. Pathways within the community garden plots lack clear sight lines in some places and would require attention if CPTED strategies were implemented. The topography also plays a role. For instance, visibility is limited in some sections of the park because of the natural topography of the park (hill). The layout of Tantolunden makes it an attractive target for offenders because of its location in the city center and its proximity to the train station and water. Urban amenities (e.g., sports facilities, shops, and restaurants) that promote outdoor activities, especially during the summer, attract hundreds of people; one unwanted consequence of this concentration of people is increased incidence of mishandling, theft, and vandalism in some sections of the park. Despite extensive efforts by authorities in Stockholm, including the police and Söderandan (a local crime prevention council that welcomes the involvement of local residents), Tantolunden Park and its surrounding area have high crime rates. Our findings show that two of the six CPTED principles (i.e., territoriality and target hardening) can easily be identified in Tantolunden Park.

A general challenge with CPTED principles is that they overlap each other when applied in practice, and this overlap does not necessarily affect safety in the same direction. Target hardening, for instance, that involves the installation of padlocks and iron bars may be a desirable form of crime prevention in some parks' high-crime spots but may compromise the esthetic value of the park and the perceived safety of park users.

Another example concerns the use of public spaces and who has the right to feel safe in them. It is evident that people naturally protect a territory they own and have respect for the territory of others. 
However, it is difficult "to keep an eye" on a public park because it is, by definition, a public good, a public space, and as such, access to it is a lawful right. Matters become more complicated because the right of an individual to access and spend time in a park is affected by everybody's right to feel safe there. Tantolunden Park poses a number of challenges in terms of crime prevention and safety because it accommodates a wide range of users - some of whom are more vulnerable to criminal victimization (e.g., homeless individuals, substance addicts) than others. Yet, these groups, by their presence alone, are declared to be a source of fear to others (both transients and residents).

Moreover, CPTED does not give guidance for dealing with the park and its relation to the environment in which it is embedded (neither neighborhood nor city context). Safety in a park should not be assessed separately from its context as it was done in this study. As an inner-city park, Tantolunden Park is surrounded by mixed land use (commerce/residential) and located in a densely inhabited, busy area of Stockholm with two main transportation hubs, making the area more susceptible to crime.

In addition, a potential weakness of CPTED is that it does not factor in the objectives of the perception of safety across seasons. For this reason, different crime and safety prevention strategies have to be developed to respond to risks that are associated with a particular season. Illumination should be particularly important in some sections of the park but not in the summer. Activity support and surveillance seem to be limited to only a very few occasions in certain times of the winter, for example, the Christmas market.

Another limitation of CPTED that goes beyond parks is that it has not yet fulfilled the objectives of sustainability, walkability, and public health (Armitage, 2014; Cozens \& Melenhorst, 2014). More specifically, Cozens, Hillier, and Prescott (2001) claimed that planners should be aware of how patterns of land use and crime intersect with individuals, family, community, and society (for more details, see Table 4). In addition, data available were not free of problems and impose a number of limitations. It should also be noted that the fieldwork data were collected in 2014, while the data used in crime mapping were from year 2008 (only available data). The limitations of using data collected 6 years before the park were visited and assessed must be kept in mind. For instance, over the 6 years' time, some additional security measures might have been installed or removed (which are unknown to us); thus, the conclusions should be drawn carefully. Moreover, police statistics revealed a number of targeted places but were not free of problems. Issues such as underreporting and changes in methods of crime reporting, which have been previously discussed in detail (Brantingham, Brantingham, \& Taylor, 2005), can also be problematic in parks. Future research should attempt to use other methods. One example is the use of safety walks, a holistic approach to safety that involves eliciting help from different groups of park users to help identify safe/unsafe places in a park (Ceccato \& Hanson, 2013). Moreover, crime mapping and field observations are useful in showing that most of the crime concentration points in Tantolunden are context-dependent and associated with crime in the surrounding areas. In the future, an analysis of context would be necessary to understand the role of the park in citywide dynamics of crime. It is also recommended to use the principles of third-generation CPTED in guidance of future interventions. For example, testing of the Information Technology (IT) interface between park users, authorities, and citizens can be carried out to improve the image of the park. Specifically, the installation of screens and wireless network information transmission can provide real-time information about events that happen in the park and in the neighborhood.

Although the results of this case study of Tantolunden Park may not be generalized to other public spaces, they provide a number of lessons, some already discussed above. A fundamental one has to do with the philosophy of CPTED principles, namely, the need to accommodate both "safety for all" and "equal access to parks" as individual rights. Finding a solution to this problem may not be best achieved by consulting experts only but rather by engaging park users and individuals responsible for park maintenance in the planning process. For now, these lessons may serve as a reference to assist researchers and urban planners in reflecting further about the usefulness of inventorying a park using CPTED principles. 


\section{Appendix}

Table Al. Park Inspection Checklist Based on CPTED Principles.

\begin{tabular}{lll}
\hline CPTED Principles & Present & Not Present \\
\hline
\end{tabular}

Surveillance

Clear sight lines

Land-use mix/activities

Natural surveillance of gathering areas

Maintenance of trees and bushes (cutting)

Buildings/windows placement

Playgrounds

Park structure/benches

Pathways

Public utilities-telephones, Automated Teller Machines (ATMs), bus shelters/stops/train/metro

Youth recreation facilities

Public toilets

Users, children, parents

Lighting levels/shadows/ pedestrian routes

Car park/underpass/overpass/crossing lighting

Needs of special groups(hearing/visual aids)

Territoriality

Site boundary definition fences, gates

Transitional space defined

Conflicting space use

Sign/cues

Access control

Sightlines

Signage

Choice of pathway routes

Problematic spots/nodes/crowding

Lawn/flooring/sidewalks

Relationship to landscape

Target hardening

Site boundary definition fences, gates

CCTV cameras

Public utilities-telephones, ATMs, bus shelters/stops/train/metro

Locks

Signage

Alarms

Activity support

Users of parks

Sports/football ground

Café

Pedestrian groups

School groups

Alcoholics

Mini golf

Kids play area

Other activities

Social cohesion and connectivity

Technological integrations for collective activities 
Table Al. (continued)

\begin{tabular}{lll}
\hline CPTED Principles & Present & Not Present \\
\hline Image of park & & \\
Maintenance (see also, Surveillance) & \\
Graffiti & \\
Litter & \\
Vandalism & \\
Others & \\
\hline
\end{tabular}

Note. $\mathrm{CPTED}=$ crime prevention through environmental design; CCTV $=$ closed-circuit television.

\section{Acknowledgments}

The authors are grateful to park users and park managers who directly contributed to this study by answering the interview. Thanks also for valuable comments on an early version of this article provided by the docent Michael Landzelius, Urban Safety and Societal Security Research Center, Gothenburg, Sweden and by the participants of the session 'Situational conditions of crime and fear' at 2015's Stockholm Symposium of Criminology, Stockholm, Sweden.

\section{Declaration of Conflicting Interests}

The authors declared no potential conflicts of interest with respect to the research, authorship, and/or publication of this article.

\section{Funding}

The authors disclosed receipt of the following financial support for the research, authorship, and/ or publication of this article: The authors acknowledge the contribution of grant 259-2012-1189 from the Swedish Research Council FORMAS.

\section{References}

Armitage, R. (2000). An evaluation of secured by design housing within West Yorkshire - Briefing note 7/00. London, England: Home Office.

Armitage, R. (2014). Crime prevention through environmental design. In G. Bruinsma \& D. Weisburd (Eds.), Encyclopedia of criminology and criminal justice (pp. 720-731). New York: Springer. Retrieved from http://link.springer.com/referencework/10.1007/978-1-4614-5690-2/page/10

Atlas, R. (2008). 21st century security and CPTED: Designing for critical Infrastructure, protection and crime prevention. Boca Raton, FL: CRC Press.

Beeler, J. (2011). Security planning for public spaces: Testing a proposed CPTED rating instrument in Berlin, Germany (A thesis presented to the graduate school of the University of Florida in partial fulfillment of the requirements for the degree of Master of Arts in urban and regional planning). University of Florida, Gainesville.

Boverket. (2010). Jämställdhet på dagordningen: Planera för ett tryggt och jämställt samhälle. Karlskrona, Sweden: Boverket (Gender equality on the agenda: Planning for a secure and equal society).

Brottsförebyggande rådet [Brå]. (2014). Crime statistics. Stockholm. Retrieved from http://www.bra.se/

Brantingham, P. L., \& Brantingham, P. J. (1984). Patterns in crime. New York, NY: Macmillan.

Brantingham, P., Brantingham, J., \& Taylor, W. (2005). Situational crime prevention as a key component in embedded crime prevention. Canadian Journal of Criminology and Criminal Justice, 47, 271-292.

Ceccato, V. (2013). Moving safely: Crime and perceived safety in Stockholm's subway stations. Plymouth, England: Lexington. 
Ceccato, V. (2014). Introduction chapter. In V. Ceccato (Ed.), The urban fabric of crime and fear (pp. 3-31). Dordrecht Heidelberg London New York: Springer. doi:10.1007/978-94-007-4210-9

Ceccato, V., \& Hanson, M. (2013). Experiences from assessing safety in Vingis park, Vilnius, Lithuania. Review of European studies, 5, 1-17.

Ceccato, V., \& Uittenbogaard, A. (2014). Space-time dynamics of crime in transport nodes. Annals of the Association of American Geographers, 104, 131-150.

Chiesura, A. (2004). The role of urban parks for the sustainable city. Landscape and Urban Planning, 68, 129-138.

City of Hamilton. (2006). Principles of CPTED (Crime Prevention Through Environmental Design) public works park and open space development manual. The Peel CPTED Advisory Committee, Hamilton. Retrieved from https://www.hamilton.ca/sites/default/files/media/browser/2014-12-18/park-open-spacedevelopment-manual-appendixh.pdf

City of Stockholm. (2006). Stockholms parkprogram-Stockholm: Kommunfullmäktige (City of Stockholm, Stockholm park programs-Stockholm: City Council). Retrieved June 10, 2011, from http://www.spacescape.se/pdf/StockholmsParkprogram2006.pdf

City of Stockholm. (2009). Stockholms stad. (2009). Stockholms översiktsplan-Stockholm: Kommunfullmaäktige (City of Stockholm, Stockholm's master plan - Stockholm: City Council). Retrieved December 1, 2012, from www.international.stockholm.se/Politics-and-organisation/Annual-reports/

City of Stockholm. (2015). Soderandan: Det lokala brottsförebyggande rådet (Southern spirit: The local crime prevention council). Retrieved from www.stockholm.se: http://www.soderandan.se/

Clark, V., \& Creswell, J. (Eds.). (2011). Designing and conducting mixed methods research (2nd ed.). Thousand Oaks, CA: Sage.

Clarke, R. (Ed.). (1997). Situational crime prevention: Successful case studies (2nd ed.). Albany, NY: Harrow and Heston. Retrieved from http://www.popcenter.org/library/reading/pdfs/scp2_intro.pdf

Clarke, R. V. (1989). Theoretical background to crime prevention through environmental design (CPTED) and situational prevention. In S. Warner \& L. Hill (Eds.), Designing out crime (pp. 13-20). Brisbane, Australia: Australian Institute of Criminology. Retrieved from http://www.aic.gov.au/media_library/conferences/ cpted/cpted.pdf

Cohen, L., \& Felson, M. (1979). Social change and crime rate trends: A routine activity approach. American Sociological Review, 44, 588-608. doi:10.2307/2094589

Cozens, P., Hillier, D., \& Prescott, G. (2001). Crime and the design of residential property-exploring the perceptions of planning professionals, burglars and other users: Part 2. Property Management, 19, 222-248.

Cozens, P., \& Melenhorst, P. (2014, July 10-12). Exploring community perceptions of crime and crime prevention through environmental design in Botswana. Paper presented at The British Society of Criminology Conference. Retrieved from http://britsoccrim.org/new/volume14/pbcc_2014_cozens.pdf

Cozens, P. M., Saville, G., \& Hillier, D. (2005). Crime prevention through environmental design (CPTED): A review and modern bibliography. Property Management, 23, 328-356.

Creswell, J., Klassen, A., Clark, V., \& Smith, K. (2010). Best practices for mixed methods research in the health sciences. Office of Behavioral and Social Sciences Research (OBSSR). Retrieved from http://obssr.od.nih. gov/mixed_methods_research/pdf/Best_Practices_for_Mixed_Methods_Research.pdf

Cubbage, C. J., \& Smith, C. L. (2009). The function of security in reducing women's fear of crime in open public spaces: A case study of serial sex attacks at a Western Australian university. Security Journal, 22, 73-86.

DeKeseredy, W. S., Donnermeyer, J. F., \& Schwartz, M. D. (2009). Toward a gendered second generation CPTED for preventing women abuse in rural communities. Security Journal, 22, 178-189.

Edwards, P., \& Tsouros, A. (2006). Promoting physical and active living in urban environments: Role of local governments. Turkey: World Health Organization.

Ekblom, P. (2010). Crime prevention, security and community safety using the 5Is framework. Basingstoke, England: Palgrave Macmillan.

Felson, M. (1995). Those who discourage crime. In J. Eck \& D. Weisburd (Eds.), Crime and place. Vol. 4 of crime prevention studies (pp. 53-66). Monsey, NY: Criminal Justice Press. 
Grönlund, B. (2012). Is Hammarby Sjöstad a model case? Crime prevention through environmental design in Stockholm, Sweden. In V. Ceccato (Ed.), The urban fabric of crime and fear (pp. 283-310). Dordrecht Heidelberg New York London: Springer.

Hilborn, J. (2009). Dealing with crime and disorder in urban parks. Problem-Oriented Guides for Police Response Guides Series, 9, 1-63. Retrieved from http://www.cops.usdoj.gov

Iqbal, A. (2012). Property values, parks and crime: A hedonic analysis in Stockholm, Sweden (Master thesis). KTH, Stockholm, Sweden. Retrieved from http://www.diva-portal.org/smash/record.jsf?pid=diva2:538544

Iqbal, A., \& Ceccato, V. (2015). Does crime in parks affect apartment prices? Journal of Scandinavian Studies in Criminology and Crime Prevention, 16, 1-25.

Jacobs, J. (1961). The death and life of great American cities. New York, NY: Vintage Books.

Jeffery, C. R. (1971). Crime prevention through environmental design. Beverly Hills, CA: Sage.

Johansson, K. (2014). Crime prevention cooperation in Sweden: A regional case study. Journal of Scandinavian Studies in Criminology and Crime Prevention, 15, 143-158.

La Vigne, N. (1996). Safe transport: Security by design on the Washington metro. Preventing mass transit crime. Monsey, NY: Criminal Justice Press.

Ley, D., \& Cybriwsky, R. (1974). Urban graffiti as territorial markers. Annals of the Association of American Geographers, 64, 491-505.

Loukaitou-Sideris, A. (1998). Urban design downtown: Poetics and politics of form. Berkeley: University of California Press.

MacDonald, J., \& Gifford, R. (1989). Territorial cues and defensible space theory: The burglar's point of view. Journal of Environmental Psychology, 9, 193-205.

Madensen, T., \& Eck, J. (2008). Violence in bars: Exploring the impact of place manager decision-making. Crime Prevention and Community Safety, 10, 111-125.

Mayhew, C. (2001). The detection and prevention of cargo theft (Trends and Issues in Crime and Criminal Justice Series 214). Canberra, Australia: Australian Institute of Criminology.

McCormick, J., \& Holland, S. (2013). Strategies in use to reduce incivilities, provide security and reduce crime in urban parks. Security Journal, 28, 1-18.

Moffat, R. (1983). Crime prevention through environmental design-A management perspective. Canadian Journal of Criminology, 25, 19-31.

Newman, O. (1972). Defensible space - Crime prevention through urban design. New York, NY: Collier Books.

Newton, A., \& Ceccato, V. (2015). Theoretical perspectives of safety and security in transit environments. In V. Ceccato \& A. Newton (Eds.), Safety and security in transit environments: An interdisciplinary approach (pp. 23-36). London, England: Palgrave Macmillan.

Police statistics. (2008). Crime statistics. Retrieved from Stockholm police headquarters Web site.

Reynald, D. (2009). Guardianship in action: Developing a new tool for measurement. Crime Prevention and Community Safety, 11, 1-20.

Reynald, D. (2014). Environmental design and crime events. Journal of Contemporary Criminal Justice, 31, 71-81. doi:10.1177/1043986214552618

Rönngren, A. (2014). När tobaken växte hög $i$ Tantolunden [When the tobacco is grown high in Tantolunden]. Retrieved May 15, 2015, from Mitti: http://www.mitti.se/nar-tobaken-vaxte-hog-i-tanto/

Rowan, M. (2006). Parks and open spaces questionnaire. London, England: GreenSpace Forum Limited.

Saville, G., \& Cleveland, G. (1998). Second generation CPTED: An antidote to the social Y2K virus of urban design. Paper presented at 3rd International CPTED Association Conference, Washington, DC.

Saville, G., \& Cleveland, G. (2008). Second-generation CPTED: The rise and fall of opportunity theory. In R. Atlas (Ed.), 21st century security and CPTED: Designing for critical infrastructure protection and crime prevention (pp. 79-90). Boca Raton, FL: CRC Press.

Schneider, R. H., \& Kitchen, T. (2002). Planning for crime prevention: A transatlantic perspective. London, England: Routledge. 
Shaw, C., \& McKay, H. (1942). Juvenile delinquency and urban areas: A study of rates of delinquency in relation to differential characteristics of local communities in American cities. Chicago, IL: University of Chicago Press.

Söderandan. (n.d.). Retrieved July 29, 2015, from Local Crime Prevention Council Web site: https://www. youtube.com/channel/UCy3JecZbpSgflFT4lnX9jRg

Södermalm District Administration. (2009). Trädplan för Tantolunden (Tree Plan for Tantolunden). Retrieved from Stockholm Stad (Stockholm city) http://www.weforum.org/reports/global-gender-gap-report-2014

Solans, N. (2013). Employee theft from passengers at US airports: An environmental criminology perspective (Doctoral Dissertation). Rutgers University, Rutgers, NJ.

Takala, H. (2004). Nordic cooperation in criminal policy and crime prevention. Journal of Scandinavian Studies of Criminology and Crime Prevention, 5, 131-147.

Teskey, M. (2013). Crime Prevention through Environmental Design (CPTED) as a design tool. CBS program, Tacoma. Retrieved from http://tacomapermits.org/wp-content/uploads/2013/09/L-1401-CPTED-Examples. pdf

Tilley, N. (Ed.). (2005). Handbook of crime prevention community safety. New York, NY: Willan publishing. United Nations Interregional Crime and Justice Research Institute. (2012). Improving urban security through Green environmental design new energy for urban security. Retrieved from UNICRI: http://www.unicri.it/ topics/urban_security/archive/urban_design/

Weisburd, D., Telep, C., \& Braga, A. (2010). The importance of place in policing: Empirical evidence and policy recommendations. Västerås, Sweden: Brå. Retrieved from https://www.bra.se/download/18. cba82f7130f475a2f1800022104/1371914732584/2010_importance_of_place.pdf

Wikström, P., Ceccato, V., Treiber, K., \& Hardie, B. (2010). Activity fields and the dynamics of crime: Advancing knowledge about the role of the environment in crime causation. Journal or Quantitative Criminology Special Edition, 26, 55-87.

Wilson, J. Q., \& Kelling, G. L. (1982). Broken windows: The police and neighbourhood safety. The Atlantic monthly. Retrieved from http://www.manhattan-institute.org/pdf/_atlantic_monthly-broken_windows.pdf

\section{Author Biographies}

Asifa Iqbal is a doctoral student at the Department of Urban Planning and Environment, School of Architecture and the Built Environment, KTH Royal Institute of Technology, Stockholm, Sweden. Her research focuses on public open spaces, urban safety, housing prices, and spatial data analysis.

Vania Ceccato is an associate professor (docent) at the Department of Urban Planning and Environment, School of Architecture and the Built Environment, KTH Royal Institute of Technology, Stockholm, Sweden. Ceccato's research is on the situational conditions of crime and crime prevention in both urban and rural environments. She is the author of Moving Safely: Crime and Perceived Safety in Stockholm's Subway Stations (2013) and Rural Crime and Community Safety (2015). 